\title{
Rainfall Variability Estimation for Western Rajasthan, India
}

\author{
Sunil Kumar Yadav*, Shweta Gautam and Sharaddha Rawat \\ Department of Environmental Science \& NRM, College of Forestry, SAM Higginbottom \\ University of Agriculture, Technology and Sciences Allahabad - 211007 (U.P.) India
}

*Corresponding author

A B S T R A C T

\begin{tabular}{|l|}
\hline Ke y w o r d s \\
$\begin{array}{l}\text { Rainfall, Variability } \\
\text { Estimation, Coefficient }\end{array}$ \\
\hline Article Info \\
\hline $\begin{array}{l}\text { Accepted: } \\
\text { 30 June } 2018 \\
\text { Available Online: } \\
\text { 10 July } 2018\end{array}$ \\
\hline
\end{tabular}

\section{Introduction}

The distribution pattern of rainfall for India is very uneven and varies considerably from year to year and region to region. In western Rajasthan district there is high dependency on rainfall. It is one of the important source of ground water recharge.

The contribution of winter, summer and PostMonsoon season's rainfall amounts to about $2 \%, 3 \%$ and $4 \%$ respectively of the annual total rainfall (Upadhyaya, 2014). The long term climatic changes related to rainfall and temperature is most likely to affect the agriculture and hydrology of whole India and definitely the Rajasthan region. Different studies have been conducted to know the inter-annual and inter-seasonal variability in rainfall. Krishnamurty and Shukla (2005) studied the inter-seasonal and seasonally persisting patterns of Indian monsoon rainfall. While the other fellow such as Gill et al., 2010 processed on the variability in climate temperature and rainfall in these different agro climatic regions of Punjab. Thus this research focuses on the variability of rainfall in western Rajasthan.

\section{Materials and Methods}

The rainfall data for the 12 districts of western Rajasthan was taken from water resources department (water.rajasthan.gov.in) for period 1986-2016. The 31 years data was future used for the rainfall variability analysis. Time series analysis such as standard deviation, coefficient of variation and mean rainfall. 


\section{Methodology}

\section{Mean rainfall}

The amount of rainfall collected by a given rain gauge in $24 \mathrm{hrs}$ is known as daily rainfall $(\mathrm{mm}$ or $\mathrm{cm})$ and the amount collected in one year in known as annual rainfall. The mean of the annual rainfall over of 35 years (in India) is known as mean annual rainfall (average annual rainfall or normal annual rainfall).

Mean Annual Rainfall $=\frac{\text { Total } \text { Rainfall }}{\text { Number of Yeras }}$

\section{Standard Deviation (SD)}

It is defined as the square root of the mean of the squares of deviations of the rainfall value from the arithmetic mean of all such rainfall. It is a measure of variability or the scatter or the dispersion about the mean value. It is given by the following formula.

$S D(\sigma)=\sqrt{\frac{\sum(X-\bar{X})^{2}}{n-1}}$

$\mathrm{X}=$ Rainfall

$\bar{X}_{=}$Mean rainfall

$\mathrm{n}=$ Number of year

\section{Coefficient of variation}

Assessment of rainfall variability through Coefficient of variation (CV \%) appears to be simple. $\mathrm{CV}$ is defined as the Standard deviation divided by the mean value of rainfall. It shows the variability of rainfall in percentage.

$$
\mathrm{CV} \%=\frac{\text { Standard Deviation }}{\text { Mean }} \times 100
$$

The greater the $\mathrm{CV}$, the lesser the dependability of receiving rainfall.
Considering the annual $\mathrm{CV}$, the IMD is using the following criteria for assessing the rainfall in a particular area.

Normal $=-19$ to $19 \%$ of annual normal rainfall.

Deficit $=-20$ to $-59 \%$ of annual normal rainfall.

Scarce $=-60 \%$ and above of annual normal rainfall

\section{Results and Discussion}

The results of this study have been presented in different subheadings as following:

\section{Decadal Rainfall analysis}

For this the 31years (starting from 1986 to 2016) rainfall data has been divided into 3 decades viz 1986-1995, 1996-2005 and 20062016 respectively district wise. In table 1 the mean and coefficient of variation of these different decades has been presented.

The lowest CV was found for the Bikaner district for the first and last decade, while for the $2^{\text {nd }}$ decade (1996-2005) the CV was least in case of Churu. For all the decades the least rainfall was observed in Jaislmer, while there is variation in maximum amount of rainfall in three decades.

The result of the study shows that the coefficient of variation during the south west monsoon was highest in Pali $(68.47 \%)$ and Jalor $(56 \%)$ district, while the lowest CV was found in the Hanumangarh district (23.99\%). Overall the range of CV for the 12 districts of western Rajasthan varied from $23.99 \%$ to $68.47 \%$ (Table 2). From the Table 2 it may be concluded that the there is high variation in the amount of rainfall in different districts of the western Rajasthan. 
Table.1 Decadal Rainfall Variability in Western Districts of Rajasthan

\begin{tabular}{|l|c|c|c|c|c|c|}
\hline DISTRICT & $\mathbf{1 9 8 6 - 1 9 9 5}$ & $\mathbf{1 9 9 6 - 2 0 0 5}$ & $\mathbf{2 0 0 6 - 2 0 1 6}$ & $\mathbf{1 9 8 6 - 1 9 9 5}$ & $\mathbf{1 9 9 6 - 2 0 0 5}$ & $\mathbf{2 0 0 6 - 2 0 1 6}$ \\
\hline & Mean Rainfall & Mean Rainfall & Mean Rainfall & CV & CV & CV \\
\hline Barmer & 301.90 & 253.40 & 334.91 & 77.43 & 42.71 & 49.17 \\
\hline Jaisalmer & 180.26 & 205.48 & 252.49 & 60.47 & 53.30 & 53.74 \\
\hline Jodhpur & 354.18 & 374.27 & 397.70 & 55.29 & 45.54 & 37.03 \\
\hline Bikaner & 253.48 & 229.00 & 356.50 & 24.22 & 52.52 & 20.89 \\
\hline Ganganagar & 252.37 & 252.80 & 350.18 & 67.57 & 50.62 & 30.45 \\
\hline Hanumangarh & 188.64 & 254.40 & 292.73 & 49.61 & 45.91 & 36.91 \\
\hline Churu & 364.40 & 408.50 & 463.00 & 31.21 & 39.68 & 32.05 \\
\hline Jhunjhunu & 392.92 & 322.00 & 463.85 & 40.94 & 45.28 & 33.27 \\
\hline Sikar & 418.70 & 499.40 & 557.73 & 40.05 & 52.54 & 42.11 \\
\hline Nagaur & 328.13 & 452.35 & 377.44 & 34.53 & 55.29 & 30.25 \\
\hline Pali & 446.61 & 377.52 & 467.72 & 59.74 & 56.72 & 38.44 \\
\hline Jalore & 469.00 & 378.49 & 462.19 & 63.11 & 42.14 & 58.48 \\
\hline
\end{tabular}

Table.2 Variability of SW monsoon of Western Rajasthan

\begin{tabular}{|c|c|c|c|c|c|c|c|c|c|c|c|c|}
\hline Months & 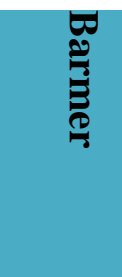 & 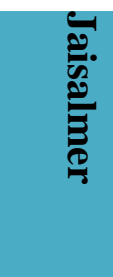 & $\begin{array}{l}\overline{\grave{2}} \\
\text { 产 } \\
\bar{E}\end{array}$ & 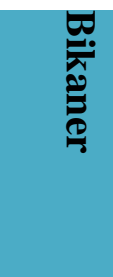 & 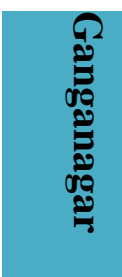 & 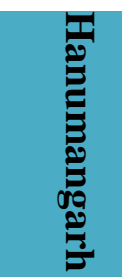 & $\stackrel{\varrho}{\Xi}$ & 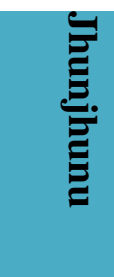 & 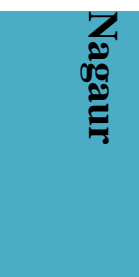 & 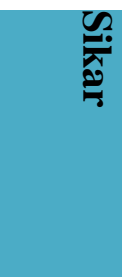 & 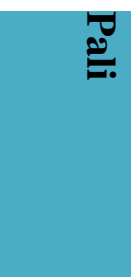 & 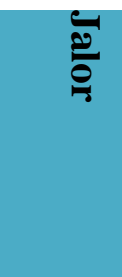 \\
\hline June & 31.0 & 26.8 & 44.7 & 42.8 & 53.6 & 40.7 & 47.2 & 50.6 & 58.8 & 71.3 & 35.1 & 52.0 \\
\hline July & 87.6 & 57.7 & 114.3 & 80.5 & 78.0 & 64.8 & 128.0 & 117.3 & 127.7 & 135.9 & 161.0 & 166.2 \\
\hline August & 99.1 & 73.8 & 128.1 & 61.6 & 97.0 & 47.1 & 114.5 & 127.7 & 117.5 & 158.9 & 154.8 & 132.7 \\
\hline September & 43.7 & 24.8 & 51.2 & 33.2 & 50.0 & 40.0 & 46.4 & 40.9 & 38.9 & 52.6 & 46.0 & 55.6 \\
\hline Total & 261.4 & 183.1 & 338.3 & 218.0 & 278.6 & 192.6 & 336.1 & 336.4 & 342.9 & 418.6 & 396.9 & 406.5 \\
\hline SD & 33.07 & 23.99 & 42.74 & 20.95 & 22.07 & 11.55 & 43.33 & 44.69 & 43.54 & 50.79 & 67.94 & 56.91 \\
\hline $\mathrm{CV}$ & 50.60 & 52.41 & 50.54 & 38.43 & 31.69 & 23.99 & 51.57 & 53.13 & 50.79 & 48.52 & 68.47 & 56.00 \\
\hline
\end{tabular}

Table.3 Variability of NE monsoon of Western Rajasthan

\begin{tabular}{|c|c|c|c|c|c|c|c|c|c|c|c|c|}
\hline Months & 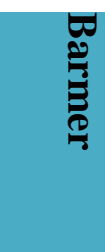 & 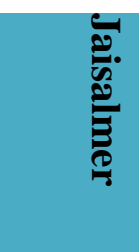 & $\begin{array}{l}\overline{\mathrm{a}} \\
\frac{\bar{E}}{\bar{E}} \\
\end{array}$ & 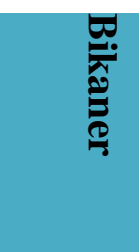 & 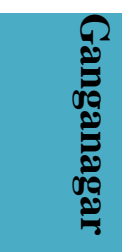 & 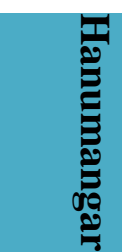 & $\stackrel{\mathcal{E}}{E}$ & 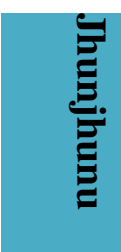 & 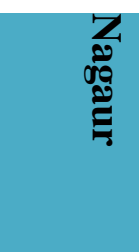 & 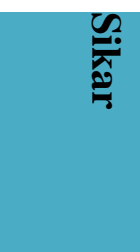 & एँ & $\overline{\frac{\partial}{2}}$ \\
\hline October & 8.8 & 3.7 & 8.3 & 14.4 & 2.9 & 5.5 & 12.3 & 7.1 & 7.8 & 18.1 & 9.3 & 11.1 \\
\hline November & 3.3 & 0.7 & 0.8 & 0.5 & 0.3 & 1.3 & 1.1 & 3.3 & 0.7 & 1.6 & 2.4 & 2.5 \\
\hline December & 1.2 & 1.9 & 0.9 & 1 & 1 & 1.5 & 2.4 & 1 & 0.5 & 2 & 1.3 & 1.1 \\
\hline Total & 13.3 & 6.3 & 10 & 15.9 & 4.2 & 8.3 & 15.8 & 11.4 & 9 & 21.7 & 13 & 14.7 \\
\hline SD & 3.92 & 4.56 & 4.3 & 7.88 & 1.34 & 2.36 & 6.12 & 3.08 & 4.15 & 9.41 & 4.33 & 5.41 \\
\hline $\mathrm{CV}$ & 88.49 & 217.14 & 129.13 & 148.68 & 95.71 & 85.51 & 116.35 & 81.05 & 138.33 & 130.15 & 100.00 & 110.41 \\
\hline
\end{tabular}


During SW monsoon the Sikar district received the highest amount of rainfall $(418.6 \mathrm{~mm})$ and Jaislmer received only $183 \mathrm{~mm}$ of rainfall Similar kind of study had been conducted by Upadhyaya, H., (2014), Which conducted that the state receives $91 \%$ of its annual rainfall due to the South-West monsoon, which is its principal rainy season.

The contribution of winter, summer and PostMonsoon season's rainfall amounts to about $2 \%, 3 \%$ and $4 \%$ respectively of the annual total rainfall. Study suggested an increase of $30 \%$ or more in precipitation over northwestern India by 2050 and an increase in probability of extreme rainfall events. The state of Rajasthan is also likely to get affected by this scenario of climate change as well, making it essential to study the variations in rainfall in the state.

The result of the study shows that the coefficient of variation during the north east monsoon was highest in Jaisalmer (217.14\%) and Bikaner (148.68\%) district, while the lowest $\mathrm{CV}$ was found in the Jhunjhunu district (81.05\%). Overall the range of CV for the 12 districts of western Rajasthan varied from $81.05 \%$ to $217.14 \%$ (Table 3 ). From the Table 3 it may be concluded that the there is high variation in the amount of rainfall in different districts of the western Rajasthan. During NE monsoon the Sikar district received the highest amount of rainfall $(21.7 \mathrm{~mm})$ and Ganganagar received only $4.2 \mathrm{~mm}$ of rainfall Similar kind of study had been conducted by Gill et al., (2010), Which conducted that the rainfall over three agro-climate region of Punjab and found that in last 40 years the Ludhiana received below normal rainfall for 24 years being highest during 1988 (1334mm) and the lowest during 1974 (379.6mm). The rainfall variability showed a SD of 210.45, 227.07 and $312.30 \mathrm{~mm}$ and $\mathrm{CV}$ of 33.70 , 30.14 and $30.46 \%$ for Bathinda, Ludhiana and Ballowal Saunkhri, respectively.
Form this study it may be conducted that there is high variation in rainfall pattern of western Rajasthan. The study of rainfall variability is important for planning and operational strategies of any agriculture crop. From the annual analysis of rainfall it was conducted that lowest rainfall was at Jaisalmer and highest at Sikar district.

\section{References}

Archer, D.R. and Fowler, H.J. (2004) Spatial and temporal variations in precipitation in the Upper Indus Basin, global teleconnections and hydrological implications. Hydrol. Earth Syst. Sci., 8, 47-61

Biswas, B.C. and Khambeta, N.K. (1974) Distribution of short period rainfall over dry farming tract of Maharashtra. $J$. Maharashtra Agric. Univ., 12: 157-168.

Gill, K.K, Bains, G.S., Mukhergee, J., Kingra, P.K., and Bal, S.K. (2010) Variability in climate in three Agroclimatic regions of Punjab. Indian J. Ecol. 37(1): 33-39.

Gupta, S. K., Babu, R. and Tejwani, K. G. (1975) Weekly rainfall of India for planning cropping programme. Soil Conserv. Digest., 3 (1): 31-36.

Krishnakumar et al., (2008) Rainfall trends in twentieth century over Kerala, India, Atmospheric Environment, Volume 43(11) pp: 1940-1944.

Krishnamurthy, V and Shukla, J. (2000) Intraseasonal and inter-annual variability of rainfall over India. J. of Climate, 13: 4366-4377.

Kumar, K. (2008) Rainfall trends in twentieth century over Kerala, India, Atmospheric Environment, Volume 43(11) pp: 19401944.

Manjunath, H., Manjunath, P.H., Sherikar, S.B. and Shreelaxmi (2014) Decadal rainfall pattern characterization and profiling of rainfall parameters over western Yadgir district, Karnataka. 
B.Tech Thesis, University of Agricultural Sciences, Raichur Karnataka (India).

Parthasarathy, B and Dhar, O.N. 1975 Trend analysis of annual Indian rainfall. Hydrologic. Sci. J., 26 (20): 257-260.

Rai, S.K., Kumar, S., Rai, A.K., Satyapriya and Palsaniya, D.R. (2014) Climate Change, Variability and Rainfall Probability for Crop Planning in Few Districts of Central India. Atmospheric and Climate Sciences, 4, 394-403.

Rajbanshi, J. (2015) Rainfall distribution and its spatial and temporal variability over damodar basin under climate change scenario (1901-2002), IOSR Journal of Environmental Science, Toxicology and Food Technology. Volume 9, Issue 9 Ver. II, PP 95-104.

Ramdurg, H., Reddy, G.V., Srinivasa, Krishnamurthy, D., Babu, B.,
Maheshwara and Nemichandrappa, M (2015) Weekly rainfall variability and probability analysis for resource planning at Hadagali, Karnataka. Internat. J. Agric. Engg., 8(2): 255-260.

Sarkar, R.P. and Biswas, B.C. (1988). A new approach to agroclimatic classification to find out crop potential. Mausam. 39 (4): 343-358.

Upadhyaya, H. (2014) Valiability of rainfall in Rajasthan (1960-2009) Int. journal of Innovative Research \& Review. Vol 2(1): 17-19

Wadood A. and Kumari P. (2009) Impact of climate change on jharkhand agriculture: mitigation and adoption, ISPRS Archives XXXVIII-8/W3 Workshop Proceedings: Impact of Climate Change on Agriculture.

\section{How to cite this article:}

Sunil Kumar Yadav, Shweta Gautam and Sharaddha Rawat. 2018. Rainfall Variability Estimation for Western Rajasthan, India. Int.J.Curr.Microbiol.App.Sci. 7(07): 4344-4348. doi: https://doi.org/10.20546/ijcmas.2018.707.506 